\title{
Systematic Review on Daily Vitamin B12 Losses and Bioavailability for Deriving Recommendations on Vitamin B12 Intake with the Factorial Approach
}

\author{
Esmée L. Doets ${ }^{a}$ Paulette H. in 't Veld ${ }^{a}$ Anna Szczecińskab \\ Rosalie A.M. Dhonukshe-Rutten ${ }^{a}$ Adrienne E.J.M. Cavelaars ${ }^{a}$ Pieter van 't Veer ${ }^{a}$ \\ Anna Brzozowska ${ }^{b}$ Lisette C.P.G.M. de Groot ${ }^{a}$ \\ ${ }^{a}$ Division of Human Nutrition, Wageningen University, Wageningen, The Netherlands; ${ }^{b}$ Department of \\ Human Nutrition, Warsaw University of Life Sciences-SGGW, Warsaw, Poland
}

\section{Key Words}

Bioavailability - EURRECA - Nutritional requirements .

Recommended dietary allowances $\cdot$ Review $\cdot$ Vitamin B12

\begin{abstract}
Aims: To systematically review the literature on daily losses and bioavailability of vitamin B12. These estimates could be used for deriving recommendations on vitamin B12 intake for adults and elderly. Methods: We identified publications on daily vitamin B12 losses (July 2011) and publications on the bioavailability of vitamin B12 from foods or diets (June 2010) in MEDLINE, EMBASE and the Cochrane Library. Results: A pooled analysis of five studies (52 subjects) showed that $0.13 \pm 0.03 \%$ of the total body store is lost per day. Absorption of vitamin B12 ranged from 4.5 (dose of $38 \mu \mathrm{g}$ from consumption of liver) to $83 \%$ (dose of $3.0 \mu \mathrm{g}$ from consumption of mutton meat). Data from eight studies including 83 subjects suggested that the amount of vitamin B12 absorbed from food $\left(A_{i}\right)$ increased with increasing doses of vitamin $B 12$ $\left(D_{i}\right)$ as described by the equation: $\ln \left(A_{i}\right)=0.7694 * \ln \left(D_{i}\right)-$ 0.9614 . Conclusion: Daily vitamin B12 losses in apparently healthy adults and elderly probably range from 1.4 to $5.1 \mu \mathrm{g}$. Vitamin B12 intakes needed to compensate for these losses seem to range from 3.8 to $20.7 \mu \mathrm{g}$. More evidence is needed
\end{abstract}

on the relationships between biochemical markers of vitamin B12 status, vitamin B12 body store and long-term health outcomes to evaluate whether current recommendations on vitamin B12 intake (1.4-3 $\mu \mathrm{g})$ need to be changed.

Copyright $\odot 2013$ S. Karger AG, Basel

\section{Introduction}

Current recommendations on vitamin B12 intake for adults and elderly vary from 1.4 to $3 \mu \mathrm{g}$ per day between European countries. The variation in these recommendations results from different approaches used for estimating vitamin B12 requirements and from different assumptions regarding the interindividual variation in requirements [1].

One of the approaches used for estimating vitamin B12 requirements for adults and elderly in Europe (The Netherlands and France) is the factorial approach, which includes a summation of daily vitamin B12 losses that need to be compensated for by dietary intake of vitamin B12. Estimates of daily vitamin B12 losses were obtained from human studies measuring (1) the decrease in radioactivity after administration of labeled vitamin B12 or (2) vitamin B12 excretion in bile [2].

\section{KARGER}

E-Mail karger@karger.com

www.karger.com/anm
(C) 2013 S. Karger AG, Basel

0250-6807/13/0624-0311\$38.00/0
Esmée L. Doets

Division of Human Nutrition, Wageningen University

PO Box 8129

NL-6700 EV Wageningen (The Netherlands)

E-Mail esmee.doets@wur.nl 
To estimate vitamin $\mathrm{B} 12$ requirements, estimates of daily vitamin B12 losses need to be corrected for bioavailability of the vitamin from the usual diet. Bioavailability is defined as 'the efficiency with which a dietary component is used systematically through normal body functions' and expressed as a percentage of intake [3]. Currently, the bioavailability of vitamin B12 is generally assumed to be 40 or $50 \%$ for healthy adults with normal gastrointestinal functioning [2,4-7]. This assumption is based on the absorption of labeled vitamin B12 from a few food products, including mutton and chicken meat, rainbow trout, eggs or fortified foods [8-12].

Recommended vitamin B12 intakes indicate the daily intake that is sufficient to fulfill requirements of nearly all apparently healthy individuals within a defined population. When the distribution of vitamin B12 requirements is known, the recommended vitamin B12 intake is derived as the average nutrient requirement (ANR) plus twice the SD of the ANR, with the ANR defined as the intake level that is sufficient to fulfill requirements in $50 \%$ of individuals in a defined population. As there is very limited evidence on the shape of this distribution, usually a standard assumption of a coefficient of variation $(\mathrm{CV})$ of $10-20 \%$ is made.

Ideally, recommended vitamin $\mathrm{B} 12$ recommendations should be based on the relationship between vitamin B12 intake, a biochemical marker of vitamin B12 status, and a cutoff level to distinguish between an adequate and an inadequate vitamin B12 status. However, so far methods to derive recommendations based on dose-response evidence are still under development and there is no strong consensus on appropriate cutoff levels for defining health [13-15]. The factorial approach may serve as an alternative until more dose-response evidence becomes available. As shown previously, European recommendations on vitamin B12 intake for adults and elderly established using the factorial approach (The Netherlands and France) are based on a limited number of studies that were published between 1963 and 2001 (box 1) [1]. Assumptions underlying these recommendations were mainly focused on the prevention of severe deficiency symptoms, whereas long-term health outcomes were not taken into account. The aim of this article was to systematically review the available literature on daily vitamin B12 losses in apparently healthy adults and bioavailability of vitamin B12 from different food sources including estimates of interindividual variation. The results of this review could serve as an input for establishing vitamin B12 recommendations using the factorial approach.
Box 1. Calculations used for establishing vitamin B12 recommendations with the factorial approach

General formula

ANR $=$ (sum of losses (feces, urine, skin, menstrual

losses...) + needs for growth)/bioavailability factor

\section{The Netherlands [6]}

Assumption 1: daily vitamin B12 losses are maximally

$0.2 \%$ of vitamin B12 stores $[11,16,17]$

Assumption 2: minimal body stores are $500 \mu \mathrm{g}$

Assumption 3: bioavailability is 50\% [8-10, 12]

Assumption 4: CV $=20 \%$

Daily losses $=0.2 \% * 500 \mu \mathrm{g}=1.0 \mu \mathrm{g}$

$\mathrm{ANR}=1.0 / 0.5=2.0 \mu \mathrm{g}$

Recommended intake $=2.0 * 1.4=2.8 \mu \mathrm{g}$

France [2]

Assumption 1: daily vitamin B12 excretion in bile is $1.4 \mu \mathrm{g}$ [18]

Assumption 2: $40 \%$ of vitamin B12 excreted in bile is reabsorbed in the small intestine $[19,20]$

Assumption 3: bioavailability is $40 \%$ [17]

Assumption 4: CV $=10 \%$

Daily losses $=1.4 * 60 \%=0.8 \mu \mathrm{g}$

$\mathrm{ANR}=0.8 / 0.4=2.0 \mu \mathrm{g}$

Recommended intake $=2.0 * 1.2=2.4 \mu \mathrm{g}$

\footnotetext{
${ }^{\text {a }}$ Recommended intake is derived as $(1+2 * \mathrm{CV} / 100) *$ ANR.
}

\section{Methods}

This systematic review was conducted according to standardized methodology as developed within the scope of EURRECA (European Micronutrient Recommendations Aligned) Network of Excellence, which is shortly described below.

Search

We conducted two systematic literature searches to identify publications on (1) basal vitamin B12 losses (MEDLINE; 12 July 2010) and (2) the bioavailability of vitamin B12 from diets (MEDLINE, EMBASE and Cochrane Library; 15 June 2010). The first search included terms on vitamin B12 or labeled vitamin B12 in combination with terms on excretion routes, kinetics or maintenance, and the second search included terms on vitamin B12 in combination with terms on absorption. Both searches were restricted to studies in humans. To be able to use the same searches to identify publications for younger population groups, no terms regarding the age of the study population were added. The second search also included terms regarding folate to identify papers on folate bioavailability, as will be described elsewhere. The search strategies are included in online supplementary file 1 (for all online suppl. material, see www.karger.com/doi/10.1159/000346968). Additional studies were identified by hand searching, i.e. screening of reference lists from all selected articles, review articles and re- 
ports including recommendations on micronutrient intakes. From July 2010 to July 2011, we checked database alerts to identify new relevant publications.

Since daily vitamin B12 losses are often reported as a proportion of the total body store of vitamin B12, we performed an additional search in MEDLINE (23 October 2012) to identify publications providing estimates of the total body store (online suppl. file 1). Search results were completed by hand searching as explained above.

\section{Study Selection and Data Extraction}

In general, studies on losses and bioavailability were eligible for inclusion when they had an experimental design and the study population included apparently healthy adults (age $\geq 18$ years) or adult patients with diseases not associated with impaired vitamin B12 metabolism or absorption. Studies on losses were included when (1) the exposure was oral or parenteral administration of vitamin B12 and (2) the outcome was an estimate of daily vitamin B12 losses measured with whole body counting (WBC) or vitamin B12 excretion in bile. Studies on bioavailability were included when (1) the exposure concerned diets, meals or individual foods in- or extrinsically labeled with vitamin B12 and (2) the outcome was a measure of fractional vitamin B12 absorption.

Studies on total body stores were included when estimates of vitamin B12 stores were obtained from apparently healthy adults or patients with diseases not associated with impaired vitamin B12 metabolism or absorption.

Four reviewers screened all titles and abstracts of papers identified through the literature searches according to the inclusion criteria, and the full text of potentially relevant papers were evaluated against the same criteria (P.H.i.t.V., A.S., M.D. and E.L.D.). For the purpose of alignment and quality control, each reviewer screened and evaluated $10 \%$ of the total number of references in duplicate with another reviewer. Each study included was extracted by a single reviewer (P.H.i.t.V. or A.S.) and a second reviewer independently verified the extracted data (E.L.D.). Any disagreement during the selection and extraction process was resolved by discussion.

From all studies, we extracted general characteristics of the study design (duration, dose) and study population (number of participants, age, gender and ethnicity). In addition, from each study reporting on total vitamin B12 losses measured with WBC, we extracted the rate of loss indicating the mean decay in radioactivity per day as a percentage of the radioactivity measured after redistribution of the labeled vitamin B12 through different body compartments (i.e. at the time that a constant excretion rate was established). The underlying assumption is that labeled vitamin B12 is distributed throughout the body in a manner similar to nonlabeled vitamin B12. We did not merely extract estimates based on measurements in healthy subjects [11, 16, 22-24] but also on subjects with low serum concentrations of vitamin B12 [23] and patients with pernicious anemia (PA) $[11,16]$, because it appeared that the rate of loss does not significantly differ between these subpopulations $[11,16,23]$. One study reported the absolute mean loss of vitamin B12 per day and the total body content of vitamin B12 [24]. To allow comparison with the other studies, the rate of loss was calculated as (mean loss per day/total body content) * $100 \%$.

From each study reporting on vitamin B12 excretion in bile, we extracted the rate of excretion, the vitamin B12 concentration of bile or the absolute vitamin B12 excreted in bile per day. The rate of excretion reflected the radioactivity measured in excreted bile as a percentage of the ingested dose minus total losses during the first 4 days (i.e. the period of redistribution of vitamin B12 throughout the body) after administration of labeled vitamin B12 $[25,26]$.

From studies on the bioavailability of vitamin B12, we extracted the percentage of the ingested dose that was absorbed. Furthermore, we extracted the absolute amount of vitamin B12 that was absorbed. In case this latter estimate was not reported, it was calculated as percent absorbed $*$ ingested dose [9, 27-29].

To describe the relationship between the amount absorbed $\left(\mathrm{A}_{\mathrm{i}}\right)$ and the dose administered $\left(\mathrm{D}_{\mathrm{i}}\right)$ via the foods provided in the intervention studies, we performed linear regression with both variables transformed to their natural logarithm in order to achieve linearity of the regression.

As an upper limit of interindividual variation, we calculated CV for each outcome measure reported per study: SD/mean * 100\%, ignoring the measurement errors and within-subject variation. When no SD was provided, we estimated it based on individual subject data $\left\{\mathrm{SD}=\sqrt{ }\left[\sum\left(\mathrm{x}_{\mathrm{i}}-\mathrm{x}_{\text {mean }}{ }^{2}\right) /(\mathrm{N}-1)\right]\right\}[8,10,11,16,22,23$, $30]$, on the standard error $(\mathrm{SE}: \mathrm{SD}=\mathrm{SE} * \sqrt{ } \mathrm{n})[25,26,31]$ or we approximated it by the total range ( $\mathrm{SD} \approx 0.25 *$ total range) [11, $25,32,33]$.

Where applicable, amounts of vitamin B12 were converted from nanomoles to micrograms using the molar weight of vitamin B12 $(1,355.38 \mathrm{~g} / \mathrm{mol})[18,29]$.

If three or more studies were comparable with regard to exposure and outcome measures, we calculated summary estimates using random-effect meta-analysis. Applying the methods of DerSimonian and Laird [34], the between-study variance is estimated, which is then used to modify the weights for calculating the summary estimate. SEs were calculated as $\mathrm{SD} / \sqrt{ } \mathrm{n}$. If no $\mathrm{SD}$ was reported and no individual data were available, we imputed an SE based on the pooled SD from the other studies included in the pooled analysis: $\mathrm{SD}_{\text {pooled }}=\sqrt{ }\left\{\sum\left[\left(\mathrm{n}_{\mathrm{i}}-1\right) * \mathrm{SD}_{\mathrm{i}}^{2}\right] / \sum\left(\mathrm{n}_{\mathrm{i}}-1\right)\right\}[24]$. Heterogeneity between studies was evaluated using the $\mathrm{I}^{2}$ statistic, which expresses the percentage of variation attributable to between-study heterogeneity rather than chance [35]. Meta-analyses were performed using STATA version 11.0 (College Station, Tex., USA), with statistical significance defined as a value of $\mathrm{p}<0.05$.

\section{Results}

\section{Study Characteristics}

In total, we identified 523 potentially relevant papers on daily vitamin B12 losses and 5,556 on bioavailability of vitamin B12 and folate (combined search). After evaluation of titles, abstracts and full texts, ten papers were included for vitamin B12 losses (five papers on daily vitamin B12 losses measured with WBC and five papers on daily vitamin B12 excretion in bile) and eight papers were included for bioavailability of vitamin B12 (fig. 1). All studies were performed in Western countries (USA, UK, Sweden, Norway or Finland). Unfortunately, information on age, sex and ethnicity of the study populations was not provided for most of the studies. Serum vitamin B12 


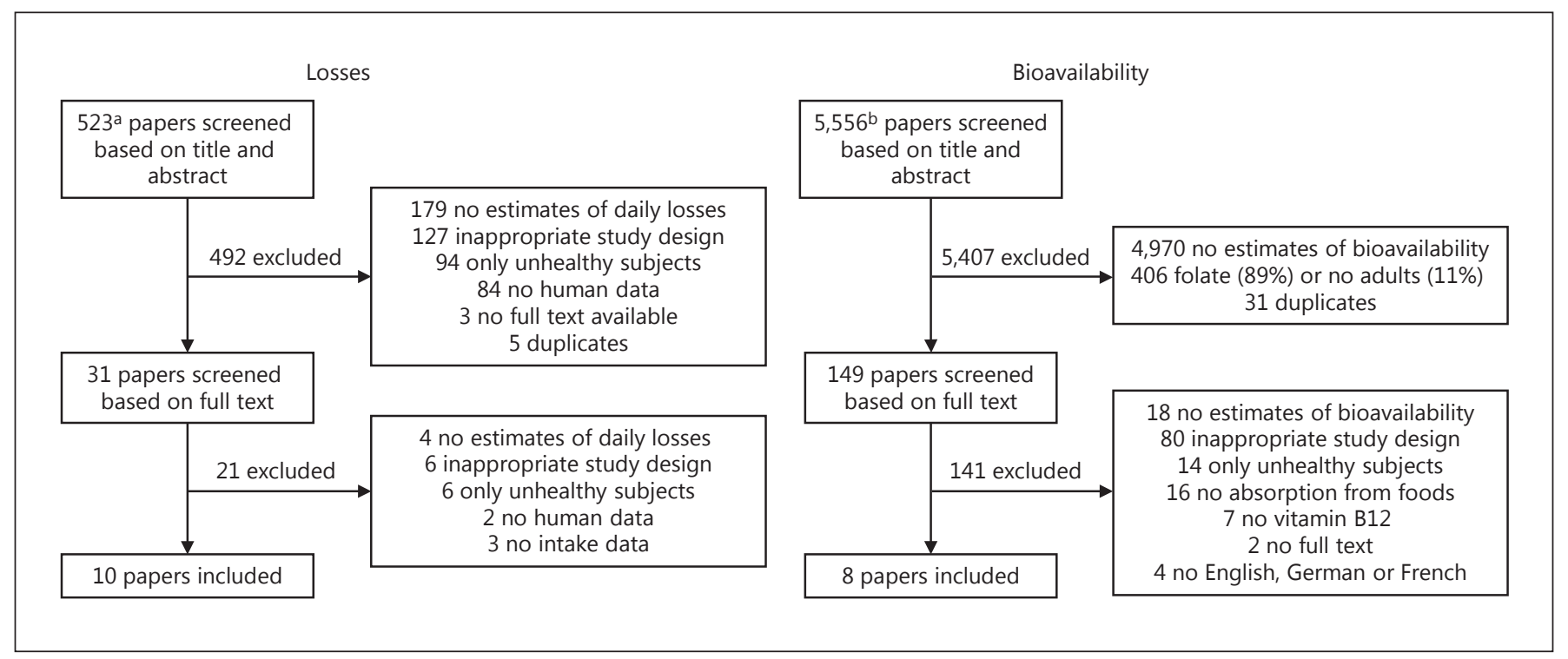

Fig. 1. Selection of studies for systematic review on daily vitamin B12 losses and bioavailability of vitamin B12. a 515 from MEDLINE, 8 identified from reference lists of selected articles and review articles. ${ }^{b}$ 5,551 from MEDLINE, EMBASE and Cochrane, 5

identified from reference lists of selected articles, review articles or recommendation reports. The multi-database search also included terms regarding folate in order to identify papers on folate bioavailability, as will be described elsewhere.

Table 1. Daily vitamin B12 losses measured with WBC

\begin{tabular}{|c|c|c|c|c|c|c|c|}
\hline \multirow[t]{2}{*}{ Reference } & \multicolumn{2}{|c|}{ Population characteristics } & \multicolumn{2}{|l|}{ Exposure } & \multicolumn{3}{|c|}{$\frac{\text { Outcome }}{\text { rate of loss, } \% \text { per day }}$} \\
\hline & $\mathrm{n}(\%$ men $)$ & health status, age, $\mathrm{n}$ & $\begin{array}{l}\text { dose of vitamin } \\
\text { B12 labeled with } \\
57 / 58 / 60 \text { Co, } \mu g^{\mathrm{a}}\end{array}$ & $\begin{array}{l}\text { adminis- } \\
\text { tration route }\end{array}$ & mean & SD & $\mathrm{CV}$ \\
\hline $\begin{array}{l}\text { Boddy and Adams } \\
\text { [23] (1968) }\end{array}$ & $14(50)$ & $\begin{array}{l}\text { healthy, } 42 \text { years }(n=1) \\
\text { low vitamin } B 12,34-74 \text { years }(n=13)\end{array}$ & 5,000 & i.v. or i.m. & 0.13 & 0.028 & 21 \\
\hline $\begin{array}{l}\text { Adams and Boddy } \\
{[22](1968)}\end{array}$ & $6(100)$ & healthy, n.a. $(n=6)$ & 0.1 & i.v. & 0.17 & 0.017 & 10 \\
\hline $\begin{array}{l}\text { Heyssel et al. } \\
\text { [11] (1966) }\end{array}$ & 14 (n.a.) & $\begin{array}{l}\text { healthy, n.a. }(\mathrm{n}=3) \\
\text { PA, n.a. }(\mathrm{n}=11)\end{array}$ & $?$ & i.m. & 0.13 & 0.02 & 15 \\
\hline
\end{tabular}
[24] (1966)

i.v. = Intravenous; i.m. = intramuscular; n.a. = not available. Values in italics are based on reported estimates or individual subject data.

${ }^{\mathrm{a}}$ In the studies of Bozian et al. [16] and Adams and Boddy [22], the radioactivity of a dose of labeled vitamin B12 was $0.5 \mu \mathrm{Ci}$. ${ }^{\mathrm{b}}$ Expressed as a percentage of the radioactivity measured after redistribution of the labeled vitamin B12 through different body compartments. ${ }^{\mathrm{c}}$ Pooled SD of other studies included in the pooled analysis. 


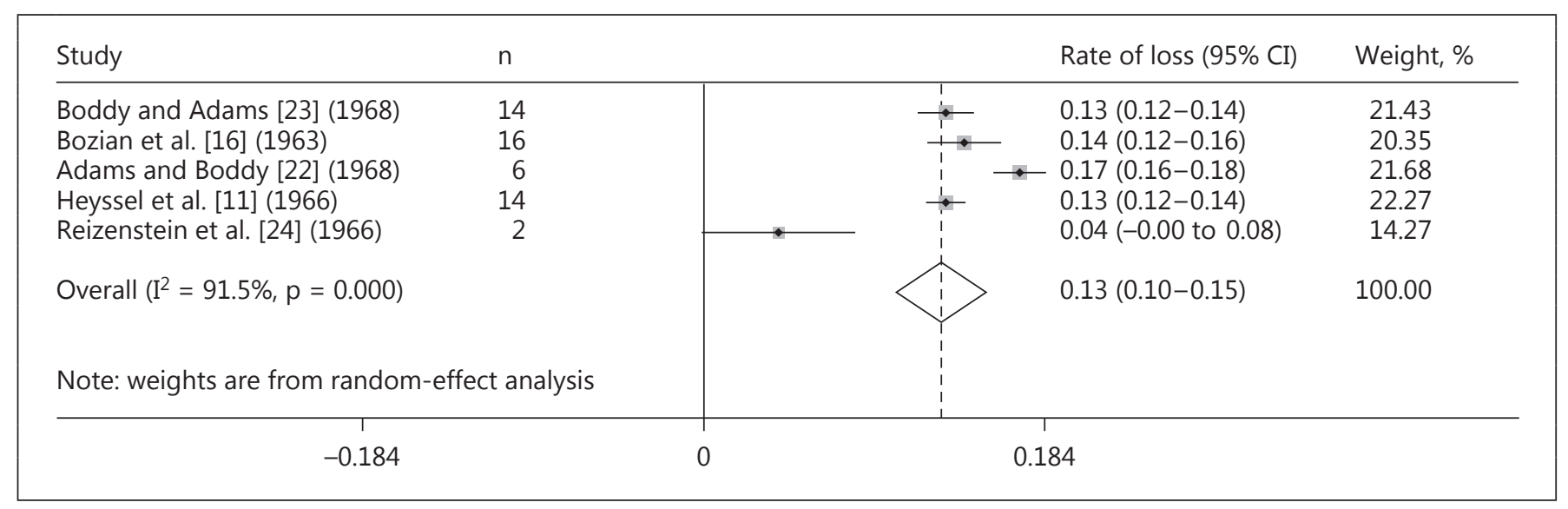

Fig. 2. Pooled analysis of the daily rate of loss of vitamin B12 as a percentage of total body stores.

concentrations were reported to be normal in all but one study that included subjects with low serum concentrations [23], but only five studies [ $8-10,27,28,36]$ actually reported concentrations (137-546 pmol/l).

The searches on vitamin B12 body stores yielded 176 hits, of which 4 could be included based on our inclusion criteria and availability of abstracts or full texts.

\section{Vitamin B12 Losses Measured with WBC}

Table 1 presents estimates of daily vitamin B12 losses measured with WBC expressed as the percentage of total body stores lost per day. Estimates were based on measurements in healthy subjects $[11,16,22-24]$, subjects with low serum concentrations of vitamin B12 [23] and PA patients $[11,16]$. Absolute amounts of vitamin B12 lost per day varied in these subpopulations, but the rate of loss was a fixed percentage of the total body store of vitamin B12, regardless of the store size: the larger the body store, the larger the losses [16, 24]. Across studies, the rate of loss varied from 0.04 (SD not available) to $0.17 \%$ per day $(S D=0.017)$. In 1966 , Reizenstein et al. [24] observed the lowest rate $(0.04 \%)$, which was based on observations in only 2 individuals. This result deviated from the other four studies that reported a rate of loss in the range of $0.13-0.17 \%$ per day $\left(\mathrm{SD}_{\text {pooled }}=0.03 \%\right)$. A meta-analysis of all five studies showed a summary estimate for the rate of loss of $0.13 \%$ per day with high heterogeneity between studies $\left(\mathrm{I}^{2}=91.5 \%, \mathrm{p}<0.0001\right.$; fig. 2 ). When the estimate of the rate of loss from the study by Reizenstein et al. [24] was omitted from the meta-analysis, the summary estimate only slightly changed to $0.14 \%$ per day (95\% confidence interval: $0.12-0.16$ ), and the observed heterogeneity between studies remained large $\left(\mathrm{I}^{2}=87.6 \%, \mathrm{p}<0.0001\right)$.

\section{Vitamin B12 Excretion in Bile}

Studies reporting on vitamin B12 excretion in bile included healthy subjects or patients with normal vitamin B12 metabolism subjected to duodenal lavage $[25,26]$, patients with postoperative drain in common bile duct $[25,26,30,37]$, patients undergoing surgery for lithiasis of the bile duct [18], patients undergoing cholecystectomy [30] or autopsy results [30]. Results of the studies included are shown in table 2 . Two studies $[25,26]$ reported on the rate of excretion, indicating similar amounts of vitamin B12 excreted in bile per day as a percentage of total body stores (rate of loss 1.1 and 1.5\%, respectively). One study measured the absolute vitamin B12 excretion in bile and the concentrations of the vitamin in bile [18], and two studies only measured concentrations of vitamin B12 in bile. Halsted et al. [37] observed no excretion of vitamin B12 in bile in 1 subject, whereas the two other studies showed mean vitamin B12 concentrations in bile of 3,248 [30] and 2,955 $\mathrm{pg} / \mathrm{ml}[18]$.

\section{Total Vitamin B12 Body Store}

Estimates of the total body store provided by the studies included ranged from 780 to $11,100 \mu \mathrm{g}$, with average values between $1,060(\mathrm{n}=4)$ [33] and 3,900 $\mu \mathrm{g}(\mathrm{n}=4-22)$ [25] (table 3). For one study [33], the health status of the subjects was not clear and the average total body store was lower compared to the other studies (1,060 vs. $2,528-$ $3,900 \mu \mathrm{g})$. 
Table 2. Daily vitamin B12 excretion in bile

\begin{tabular}{|c|c|c|c|c|c|c|c|c|}
\hline \multirow[t]{3}{*}{ First author } & \multirow[t]{3}{*}{$\mathrm{n}$} & \multirow{3}{*}{$\begin{array}{l}\text { Population characteristics } \\
\text { health status, age, } \mathrm{n}\end{array}$} & \multicolumn{2}{|l|}{ Exposure } & \multicolumn{4}{|l|}{ Outcome } \\
\hline & & & \multirow{2}{*}{$\begin{array}{l}\text { dose of vitamin B12 } \\
\text { labeled with } \\
57 / 58 / 60 \mathrm{Co}, \mu \mathrm{g}^{\mathrm{a}}\end{array}$} & \multirow{2}{*}{$\begin{array}{l}\text { administra- } \\
\text { tion route }\end{array}$} & \multirow[t]{2}{*}{ outcome measure } & \multicolumn{3}{|l|}{ result } \\
\hline & & & & & & mean & $\mathrm{SD}$ & $\mathrm{CV}$ \\
\hline $\begin{array}{l}\text { Reizenstein } \\
\text { [26] (1959) }\end{array}$ & 14 & $\begin{array}{l}\text { healthy, } 20-34 \text { years, n.a. } \\
\text { patients with irrelevant diseases }{ }^{\mathrm{b}} \text {, } \\
16-69 \text { years, n.a. } \\
\text { patients with postoperative drain in } \\
\text { common bile duct, n.a. }\end{array}$ & $0.3-0.6$ & i.m. & rate of loss, $\% /$ day $^{c}$ & 1.5 & 1.2 & 77 \\
\hline $\begin{array}{l}\text { Grasbeck } \\
\text { [25] (1958) }\end{array}$ & 7 & $\begin{array}{l}\text { healthy, n.a. }(\mathrm{n}=2) \\
\text { patients with postoperative T-tube } \\
\text { drain common bile duct, n.a. }(\mathrm{n}=5)\end{array}$ & 0.5 & i.m. & rate of loss, $\% /$ day $^{c}$ & 1.1 & 0.8 & 72 \\
\hline $\begin{array}{l}\text { el Kolthy } \\
{[18](1991)}\end{array}$ & 8 & $\begin{array}{l}\text { patients undergoing surgery for } \\
\text { lithiasis of the bile duct, } \\
62-70 \text { years }(n=8)\end{array}$ & $?$ & oral & $\begin{array}{l}\text { absolute loss, } \mu \mathrm{g} / \mathrm{day} \\
\text { concentration in bile, } \\
\mathrm{pg} / \mathrm{ml}\end{array}$ & $\begin{array}{l}1.4 \\
2,955\end{array}$ & $\begin{array}{l}0.60 \\
1,003\end{array}$ & $\begin{array}{l}42 \\
34\end{array}$ \\
\hline $\begin{array}{l}\text { Ardeman } \\
{[30](1965)}\end{array}$ & 6 & $\begin{array}{l}\text { drain in bile duct, n.a. }(\mathrm{n}=4) \\
\text { cholecystectomy, n.a. }(\mathrm{n}=1) \\
\text { autopsy, n.a. }(\mathrm{n}=1)\end{array}$ & none & - & $\begin{array}{l}\text { concentration in bile, } \\
\mathrm{pg} / \mathrm{ml}\end{array}$ & 3,248 & 4,314 & 133 \\
\hline $\begin{array}{l}\text { Halsted } \\
{[37](1956)}\end{array}$ & 1 & $\begin{array}{l}\text { T-tube in common bile duct, } \\
\text { n.a. }(\mathrm{n}=1)\end{array}$ & 2.0 & oral & $\begin{array}{l}\text { concentration in bile, } \\
\mathrm{pg} / \mathrm{ml}\end{array}$ & 0 & - & - \\
\hline
\end{tabular}

i.m. = Intramuscular; n.a. = not available. Values in italics are based on reported estimates or individual subject data.

a The radioactivity of a dose of labeled vitamin B12 ranged from 0.1 to $1.2 \mu \mathrm{Ci}$. ${ }^{\mathrm{b}}$ Diagnosis were asthenia and achlorhydria, allergic bronchial asthma, diabetes mellitus and acute or subacute nephritis. All patients showed normal serum vitamin B12 concentrations and normal vitamin B12 absorption tests. ${ }^{c}$ Expressed as percent of total body stores.

Table 3. Total body stores of vitamin B12

\begin{tabular}{|c|c|c|c|c|c|c|c|}
\hline \multirow[t]{2}{*}{ First author } & \multicolumn{2}{|c|}{ Study population } & \multicolumn{5}{|l|}{ Outcome } \\
\hline & $\mathrm{n}$ & health status & outcome measure & $\begin{array}{l}\text { average } \\
\text { stores, } \mu g\end{array}$ & $\begin{array}{l}\text { range of } \\
\text { stores, } \mu \mathrm{g}\end{array}$ & $\mathrm{SD}$ & $\begin{array}{l}\mathrm{CV} \\
\%\end{array}$ \\
\hline Grasbeck [25] (1958) & $4-22$ & autopsies & $\begin{array}{l}\text { sum of vitamin B12 content in liver, } \\
\text { kidneys, heart, spleen, brain, muscles }\end{array}$ & 3,900 & $790-11,100$ & 2,578 & 66 \\
\hline Reizenstein [24] (1966) & n.a. & healthy controls & whole body content & 3,030 & n.a. & n.a. & n.a. \\
\hline Adams [32] $(1970)^{\mathrm{a}}$ & 18 & patients for surgery & whole body content & 2,528 & $960-5,984$ & 1,256 & 50 \\
\hline Bessent [33] $(1980)^{\mathrm{a}}$ & 4 & n.a. control/treated PA patients & whole body content & 1,060 & $780-1,350$ & 143 & 13 \\
\hline
\end{tabular}

n.a. $=$ Not available. ${ }^{\text {a }}$ Based on abstract only.

\section{Bioavailability of Vitamin B12}

We did not identify any study that assessed bioavailability of vitamin B12 from specific diets. All studies rather addressed absorption of vitamin B12 from a specific food product alone or in combination with a meal free of vitamin B12. Study populations included healthy subjects and subjects with a disease not affecting vitamin B12 absorption. Table 4 shows quantitative estimates of absorp- tion obtained by the fecal excretion method [38] or WBC based on observations in 2-13 subjects per study [11]. Overall, absorption ranged from $4.5 \%$ at a dose of $38 \mu \mathrm{g}$ from liver to $83 \%$ at a dose of $3.03 \mu \mathrm{g}$ from mutton meat [11]. CVs for absorption estimates within studies ranged from 11 to $84 \%$, whereas SDs were more similar ranging from 1.7 [11] to $22 \%$ [29], with most estimates in the range of $5.2-14 \%$. 
Table 4. Bioavailability of vitamin B12 from different food products

\begin{tabular}{|c|c|c|c|c|c|c|c|c|}
\hline \multirow[t]{3}{*}{ First author } & \multicolumn{2}{|c|}{ Population characteristics } & \multicolumn{2}{|l|}{ Exposure } & \multicolumn{4}{|c|}{ Outcome } \\
\hline & \multirow[t]{2}{*}{$\mathrm{n}$} & \multirow[t]{2}{*}{ health status, age } & \multirow[t]{2}{*}{ food product } & \multirow{2}{*}{$\begin{array}{l}\text { dose of vitamin } \\
\text { B12 labeled with } \\
57 / 58 / 60 \mathrm{Co}, \mu \mathrm{g}^{\mathrm{a}}\end{array}$} & \multicolumn{3}{|c|}{$\%$ absorbed } & \multirow{2}{*}{$\begin{array}{l}\text { mean } \\
\text { amount } \\
\text { absorbed, } \mu \mathrm{g}\end{array}$} \\
\hline & & & & & mean & $\mathrm{SD}$ & $\mathrm{CV}$ & \\
\hline \multicolumn{9}{|c|}{ Fecal excretion method } \\
\hline $\begin{array}{l}\text { Doscherholmen } \\
\text { [28] (1973) }\end{array}$ & 11 & $\begin{array}{l}\text { healthy, } \\
23-55 \text { years }\end{array}$ & scrambled whole egg & 0.56 & 28 & - & - & 0.15 \\
\hline \multirow{4}{*}{$\begin{array}{l}\text { Doscherholmen } \\
\text { [9] (1975) }\end{array}$} & 5 & healthy & \multirow{4}{*}{$\begin{array}{l}\text { scrambled egg yolk } \\
\text { scrambled whole egg } \\
\text { boiled egg } \\
\text { fried egg }\end{array}$} & 0.5 & 36 & \multirow[t]{4}{*}{-} & \multirow[t]{4}{*}{-} & 0.18 \\
\hline & 6 & healthy & & 0.56 & 28 & & & 0.15 \\
\hline & 4 & healthy & & $0.51-0.94$ & 24 & & & $0.12-0.23$ \\
\hline & 4 & healthy & & $0.51-0.94$ & 24 & & & $0.12-0.23$ \\
\hline $\begin{array}{l}\text { Doscherholmen } \\
\text { [27] (1976) }\end{array}$ & 13 & healthy & scrambled egg white & $0.30-0.62$ & 36 & - & - & $0.11-0.22$ \\
\hline \multirow{3}{*}{$\begin{array}{l}\text { Doscherholmen } \\
\text { [16] }(1978)^{\mathrm{c}}\end{array}$} & 3 & healthy & \multirow{3}{*}{$\begin{array}{l}\text { cooked chicken meat } \\
(100,200 \text { or } 300 \mathrm{~g})\end{array}$} & $0.42-0.64$ & 65 & 8.4 & 13 & 0.35 \\
\hline & 3 & & & $0.84-1.28$ & 63 & 13.9 & 22 & 0.68 \\
\hline & 3 & & & $1.26-1.92$ & 61 & 13.1 & 22 & 1.0 \\
\hline \multirow{4}{*}{$\begin{array}{l}\text { Doscherholmen } \\
\text { [8] }(1981)^{c}\end{array}$} & 2 & healthy & \multirow{4}{*}{$\begin{array}{l}\text { cooked rainbow trout } \\
(50,100,200 \text { or } 300 \mathrm{~g})\end{array}$} & $1.95-2.18$ & 42 & 5.9 & 14 & 0.87 \\
\hline & 3 & & & 3.90 & 38 & 8.1 & 22 & 1.5 \\
\hline & 3 & & & $7.80-10.90$ & 41 & 7.5 & 18 & 3.9 \\
\hline & 3 & & & $11.7-15.6$ & 30 & 5.2 & 17 & 4.0 \\
\hline $\begin{array}{l}\text { Reizenstein } \\
\text { [31] (1959) }\end{array}$ & 11 & $\begin{array}{l}\text { healthy or irrelevant } \\
\text { diseases }^{\text {b }}, 17-38 \text { years }\end{array}$ & raw pig/calf liver & 22 & 30 & 14 & 47 & 6.0 \\
\hline \multirow{4}{*}{$\begin{array}{l}\text { Kittang [26] } \\
(1985)^{\mathrm{c}}\end{array}$} & 6 & \multirow[t]{4}{*}{ healthy, mean 31 years } & \multirow[t]{4}{*}{ boiled/fried rabbit liver } & 0.50 & 49 & 22 & 45 & 0.24 \\
\hline & 6 & & & 1.0 & 34 & 10 & 29 & 0.34 \\
\hline & 6 & & & 1.5 & 26 & 8.4 & 32 & 0.39 \\
\hline & 6 & & & 3.0 & 10 & 8.4 & 84 & 0.31 \\
\hline \multicolumn{9}{|c|}{ Whole body counting } \\
\hline Heyssel [11] & 3 & healthy young & mutton lean meat & 0.95 & 65 & 11 & 17 & 0.62 \\
\hline \multirow{4}{*}{$(1966)$} & 2 & healthy young & mutton lean meat & 3.03 & 83 & 9.2 & 11 & 2.5 \\
\hline & 2 & healthy young & mutton lean meat & 5.11 & 52 & 16 & 32 & 2.7 \\
\hline & 6 & healthy young & mutton liver pâté & 38 & 11 & 6.0 & 55 & 4.1 \\
\hline & 4 & healthy old & mutton liver pâté & 38 & 4.5 & 1.7 & 38 & 1.7 \\
\hline
\end{tabular}

Values in italics are based on reported estimates or individual subject data.

${ }^{a}$ In the studies of Doscherholmen $(1973,1975,1981)$, radioactivity of a dose of labeled vitamin B12 ranged from 0.05 to $1.02 \mu C i{ }^{b}$ Irrelevant diseases included hypoplastic anemia and mediastinal tuberculosis. ${ }^{c}$ Repeated measures in same subjects.

For specific food groups and doses, absorption ranged from 24 to $36 \%$ for egg products (dose $0.3-0.94 \mu \mathrm{g}$ ), from 52 to $83 \%$ for lean meat (dose $0.54-5.11 \mu \mathrm{g}$ ), from 30 to $42 \%$ for fish (dose $2.1-13.1 \mu \mathrm{g}$ ) and from 4.5 to $49 \%$ for liver products (dose $0.5-38 \mu \mathrm{g}$ ). Four studies measured absorption from a food product with varying vitamin B12 contents. In two of four studies, percent absorption decreased with increasing vitamin B12 content [10, 29], whereas the other two did not show such a clear trend $[8$, $11]$.

The percentages of absorption mentioned above suggest very heterogeneous absorption of vitamin B12 from different sources. However, when expressed as dose-response relationship, it appeared that the dose taken, rather than the food source, as such influences the amount absorbed. Overall, the amount of vitamin B12 absorbed $\left(\mathrm{A}_{\mathrm{i}}\right)$ increased with increasing vitamin $\mathrm{B} 12$ doses $\left(\mathrm{D}_{\mathrm{i}}\right)$, and the relationship was estimated as $\ln \left(\mathrm{A}_{\mathrm{i}}\right)=0.7694^{*}$ $\ln \left(D_{i}\right)-0.9614$, as illustrated in figure 3. Since we applied a natural logarithmic transformation on both the vitamin B12 dose and the amount of vitamin B12 absorbed, the regression coefficient of 0.7694 means that for every doubling in vitamin B12 dose, the difference in absorbed amount is $2^{0.7694}(=1.70)$, which is $70 \%$. 
Fig. 3. Absorbed amounts of vitamin B12 for different doses and food groups. Both the dose and the absorbed amount were transformed to their natural logarithm in order to achieve linearity of the regression. Values of $0,1,2,3$ and 4 on the $\mathrm{x}$-axis correspond to labeled vitamin B12 doses of $1.0,2.7,7.4,20.1$ and $54.6 \mu \mathrm{g}$, respectively. Values of $-2,-1,0,1$ and 2 on the $y$-axis correspond to absorbed vitamin B12 of 0.1, $0.4,1.0,2.7$ and $7.4 \mu \mathrm{g}$, respectively.

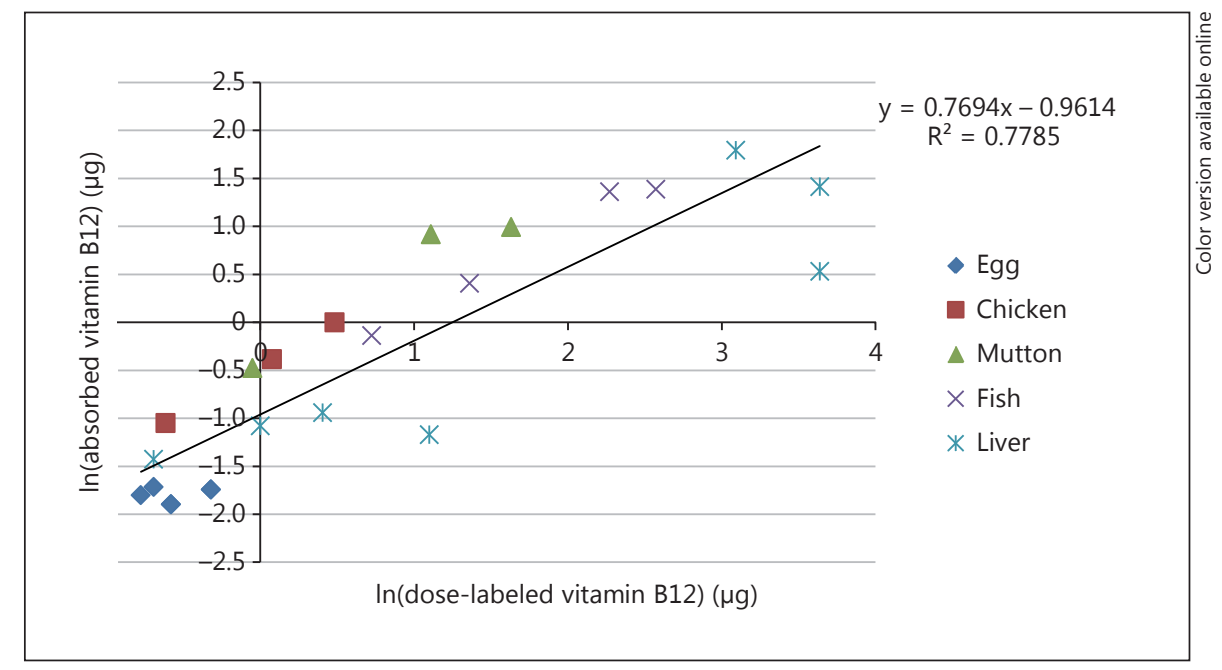

\section{Discussion}

\section{Main Findings}

In Europe, ANRs for vitamin B12 established with the factorial approach are currently based on the study selection, as summarized in this review. This systematic review indicates that the total amount of vitamin B12 lost per day is $0.13 \%(\mathrm{CV}=23 \%)$ of the total body store, with mean values between 1.1 and $3.9 \mathrm{mg}$. Observations of the rate of vitamin B12 excretion in bile were similar (1-1.5\% of the total body store per day, $\mathrm{CV}=72-77 \%$ ), whereas the absolute amount of vitamin B12 excreted in bile per day and vitamin B12 concentrations in bile varied largely between and within studies (CV within studies $=34-133 \%$ ). Estimates of vitamin B12 absorption varied between 4.5 and $83 \%$ (CV 11-84\%) based on studies with varying vitamin $\mathrm{B} 12$ contents and different types of food products. The relationship between the amount absorbed $\left(\mathrm{A}_{\mathrm{i}}\right)$ and the dose of vitamin $\mathrm{B} 12$ ingested $\left(\mathrm{D}_{\mathrm{i}}\right)$ was estimated as $\ln \left(A_{\mathrm{i}}\right)=0.7694 * \ln \left(\mathrm{D}_{\mathrm{i}}\right)-0.9614$.

\section{Implications of Our Findings for Estimates of Vitamin B12 Requirements \\ Interindividual Variation in Requirements}

Most studies reporting on daily vitamin B12 losses or absorption are old, include a small number of subjects and details on the study subjects are very limited. Moreover, we observed a large variation between and within studies, especially among studies reporting on vitamin B12 excretion in bile. Estimating vitamin B12 requirements with the factorial approach, as in the Netherlands, requires assumptions regarding the rate of loss, the total body store and bioavailability (box 1). Each assumption is a component of uncertainty and following the simple error-propagation formula for independent measurements, for any given value of the body store, the $\mathrm{CV}$ of the ANR for vitamin B12 can be estimated as: $\checkmark\left(\mathrm{CV}^{2}\right.$ rate of loss $+\mathrm{CV}^{2}$ bioavailability $)$. Based on the observations of within-study variation for the rate of loss $(\mathrm{CV}=$ $23 \%$, based on the pooled SD) and bioavailability (CV = $8-81 \%$ ), this would imply a CV for the ANR of at least $24 \%$. These calculations suggest that the CV exceeds the $20 \%$ currently assumed for estimating recommended intakes of vitamin B12 in the Netherlands. However, it must be noted that the CVs used in these calculations are based on studies with few subjects, which may result in an overestimation of the interindividual variation. Moreover, there is some evidence that lower body stores of vitamin B12 go together with higher absorption [26], as for many other nutrients. If bioavailability of vitamin B12 depends on the total body store, the CV of vitamin B12 requirements may be less than predicted with the error-propagation formula.

The French recommended intake of vitamin B12 is derived as the ANR multiplied by 1.2 (2 times a CV of $10 \%$ ). However, this review showed that measures of vitamin B12 excretion in bile vary largely between and within studies (CV: 34-133\%). So, considering the additional assumptions required for estimating vitamin B12 requirements based on daily losses in bile (\% reabsorption from the intestine, \% bioavailability), it seems likely that a CV of $10 \%$ underestimates the interindividual variation and uncertainty in requirements. 
Table 5. Summary of vitamin B12 requirements estimated with the factorial approach based on different assumptions

\begin{tabular}{|c|c|c|c|c|c|}
\hline $\begin{array}{l}\text { Daily losses } \\
\text { (based on WBC) }\end{array}$ & 5 & $\begin{array}{l}\text { rate of loss } \\
0.13 \%\end{array}$ & body stores: $1.1-3.9 \mathrm{mg}$ & $1.4-5.1$ & $8.7-20.7$ \\
\hline \multirow[t]{2}{*}{$\begin{array}{l}\text { Daily losses } \\
\text { (based on excretion in bile) }\end{array}$} & 2 & $\begin{array}{l}\text { rate of loss } \\
1.1-1.5 \%\end{array}$ & $\begin{array}{l}\text { body stores: } 1.1-3.9 \mathrm{mg} \\
67 \% \text { reabsorption }\end{array}$ & $3.8-19.3$ & $14.5-117.7$ \\
\hline & $\overline{1}$ & $\begin{array}{l}\text { absolute amounts in bile } \\
1.4 \mu \mathrm{g}\end{array}$ & $67 \%$ reabsorption & 0.5 & 0.9 \\
\hline
\end{tabular}

${ }^{a} \ln ($ the amount absorbed $)=0.7694 * \ln ($ intake $)-0.9614$, assuming that total losses should be compensated by three meals a day containing equal amounts of vitamin B12.

Total Vitamin B12 Losses Measured with WBC

Current recommendations based on the factorial approach include the assumption that compensation of daily losses will be sufficient to maintain the vitamin B12 body store and thereby prevent deficiency disorders. Estimates of the body store $(500 \mu \mathrm{g})$ were based on observations in patients suffering from malabsorption that remained both hematologically normal (no megaloblastic changes of the bone marrow, no anemia and no macrocytosis) and serum vitamin B12 concentrations at 96-148 $\mathrm{pmol} / \mathrm{l}$. The selection of the hematological status as a criterion for adequacy may be debatable for several reasons. Although the biological role of vitamin B12 in blood cell formation is well defined [39-41], it has been estimated that $19-28 \%$ of patients with PA do not have anemia, and $17-33 \%$ have a normal mean cell volume $[42,43]$. Secondly, potentially irreversible neurologic disorders due to vitamin B12 deficiency may occur in the absence of anemia or an elevated mean cell volume [44-46]. It is even suggested that the occurrence of neurological complications is inversely correlated with the degree of anemia; patients who are less anemic show more prominent neurological complications and vice versa [47, 48]. Moreover, recommendations on micronutrient intake are designed for apparently healthy populations, and therefore it may be more appropriate to use estimates of body stores based on apparently healthy subjects for estimating daily losses. Our review on total body stores of vitamin B12 showed that in adults mean total body stores are between 1.1 and $3.9 \mathrm{mg}$. This is in line with reported mean values on vitamin B12 liver content (0.7-1.0 $\mu \mathrm{g} / \mathrm{g}$ liver) [49-53] and liver weights [men: 1,677 g (range: 670-2,900), wom- en: $1,475 \mathrm{~g}$ (range 508-3,081) [54]] assuming that half of vitamin B12 in the human body is stored in the liver [39]. Based on these stores and a rate of loss of $0.13 \%$ of the store per day, total losses would range from 1.4 to $5.1 \mu \mathrm{g}$ per day under the assumption that the size of the total body store of vitamin B12 is the major determinant of the amount of vitamin B12 lost per day (table 5).

\section{Vitamin B12 Excretion in Bile}

The absolute amount excreted in bile per day was 1.4 $\mu \mathrm{g}$ in one study. Based on the reported mean rate of loss of 1.1 or $1.5 \%$ of the total body store and assuming that body stores range from 1.1 to $3.9 \mathrm{mg}$, as also referred to above, daily vitamin B12 excretion in bile may range from 12 to $59 \mu \mathrm{g}$. Daily biliary excretion of vitamin B12 derived from the reported concentration of the vitamin in bile was $1.6 \mu \mathrm{g}$ per day, assuming a daily output of bile of 493 $\mathrm{ml}[18]$. So, using the French assumption that $40 \%$ of vitamin B12 excreted in bile is reabsorbed in the small intestine (box 1), total losses of vitamin B12 range from 0.8 to $35 \mu \mathrm{g}$ per day. It must be noted, however, that in two studies included in this review, excretion of vitamin B12 was measured both in bile and in feces, and results showed that losses in feces were about one third (28-33\%) of the amount of vitamin B12 excreted in bile $[25,26]$. This would imply that more than two thirds of the vitamin B12 excreted in bile are reabsorbed in the small intestine and that daily losses range from 0.5 to $19 \mu \mathrm{g}$ per day (table 5).

\section{Bioavailability of Vitamin B12}

Absorption of vitamin B12 from food is influenced by the type of food source and its vitamin B12 content, as 
shown in this review and in other publications $[4,7]$. Studies included in our review measured amounts absorbed up to $6 \mu \mathrm{g}$ from a single meal. This is not consistent with previous data showing that the average maximum amount of vitamin B12 that can be absorbed from amounts usually consumed with a meal is about $1.5 \mu \mathrm{g}$ due to saturation of the vitamin B12 intrinsic factor receptors, which are key factors in the absorption of vitamin B12 from the ileum [39]. Although passive diffusion of $1 \%$ of the ingested dose also takes place, this only becomes relevant when high doses are ingested, e.g. via supplements.

In general, absorption of $50 \%$ from the diet was assumed for estimating vitamin B12 requirements. Although two studies observed vitamin B12 absorption $>50 \%$ (chicken or mutton meat), absorption from other food products was $<50 \%$ at doses of $0.5-5 \mathrm{mg}$. In addition, usual vitamin B12 intake among adults and elderly people across Europe ranges from 3.5 to $9.3 \mu \mathrm{g}$ per day [55]. Assuming that each day three meals contribute to vitamin $\mathrm{B} 12$ intake, and that these three meals contain equal amounts of vitamin B12 (1.2-3.1 $\mu \mathrm{g}$ per meal), the regression equation derived in this review $\left[\ln \left(\mathrm{A}_{\mathrm{i}}\right)=\right.$ $\left.0.7694 * \ln \left(D_{i}\right)-0.9614\right]$ could be used to predict the bioavailability as follows:

$$
\begin{aligned}
& \ln (\text { bioavailability })= \\
& \ln (\mathrm{A} / \mathrm{D})=\ln (\mathrm{A})-\ln (\mathrm{D})=(0.7694-1) * \ln (\mathrm{D})-0.9614 \\
& \text { and bioavailability }= \\
& (1.2-3.1 \mu \mathrm{g})^{(0.7694-1)} *\left(\mathrm{e}^{-0.9614}\right) \text {, which amounts to } 29-37 \% .
\end{aligned}
$$

This suggests that the generally assumed 50\% overestimates real absorption, potentially leading to an underestimation of the requirements. Moreover, as it is suggested that there is a maximum amount of vitamin B12 that can be absorbed per meal, it does not seem right to report on the percent absorption of a specific food without referring to the actual dose ingested [4].

Unfortunately, the regression equation was based on absorption data from a limited number of food products. For example, no estimates of vitamin B12 absorption from foods such as dairy products were included that are widely consumed in Europe. Results from some observational studies suggest that absorption from dairy products, especially milk, may be higher than that from other dietary sources [56, 57]; however, so far, these results are not verified by experimental studies.

Vitamin B12 Requirements

Based on the estimates of daily vitamin B12 losses and the regression equation derived in this review, the dietary vitamin $\mathrm{B} 12$ intake needed to compensate daily losses would range from 3.8 to $20.7 \mu$ g per day based on WBC measurements or from 0.9 to $118 \mu \mathrm{g}$ per day based on excretion in bile (table 5) assuming that three meals a day equally contribute to vitamin B12 intake. These intake ranges indicate the daily intake necessary to maintain the body store in apparently healthy adults and elderly people rather than the intake level at which requirements of $50 \%$ of individuals in a population are fulfilled since it is unknown what stores reflect which state of deficiency or sufficiency [13]. Therefore, the intake ranges reflect the recommended vitamin B12 intake rather than the ANR.

As vitamin B12 requirements based on the excretion in bile vary largely depending on the total body stores assumed, these estimates seem less adequate for deriving recommended vitamin B12 intakes. Although vitamin B12 requirements based on total losses measured with WBC vary with a factor of five depending on the assumed total body stores, these estimates are in line with findings from five studies that showed that plasma concentrations of markers for vitamin B12 status (total cobalamin, methylmalonic acid and holotranscobalamin II) leveled off at daily intakes between 4 and $10 \mu g$ per day [56-60]. Daily intakes between 4 and $10 \mu \mathrm{g}$ per day will therefore likely be adequate for the prevention of subclinical deficiencies in vitamin B12 that may be associated with potential health risks, including neurologic and cognitive risks [61]. However, more evidence is needed on the relationship between plasma concentrations of markers for vitamin B12 status, vitamin B12 body stores and long-term health outcomes to define whether it is beneficial to maintain maximal vitamin B12 status and stores of 1.1-3.9 mg.

It must be noted that all studies included in our review were based on subjects with normal absorption. At the age of $\geq 60$ years, the prevalence of food-bound malabsorption increases, which is a primary cause for vitamin B12 deficiency affecting about $20 \%$ of the elderly in industrialized countries [62]. Food-bound malabsorption is characterized by the inability to release vitamin B12 from food or from intestinal transport proteins. Therefore, this vitamin B12 cannot or only partly bind to the intrinsic factor, and so absorption of vitamin B12 does not take place or only to a lesser extent. Absorption of crystalline vitamin B12 is usually not affected in subjects with food-bound malabsorption, and therefore most European countries recommend elderly people to consume a high proportion of their vitamin B12 intake as fortified foods and supplements [1]. In two studies investigating absorption from bread, squash or milk fortified with $0.25-0.5 \mu \mathrm{g}$ vitamin B12, an absorption between 55 and $74 \%$ was observed $[12,36]$. 


\section{Conclusions}

This review showed that daily vitamin B12 losses in apparently healthy adults and elderly probably range from 1.4 to $5.1 \mu \mathrm{g}$. Based on the relationship between the ingested dose and the amount absorbed, vitamin B12 intakes needed to compensate for these daily losses seem to range from 3.8 to $20.7 \mu \mathrm{g}$ in apparently healthy adults and elderly people, which is 1.4-8.6 times higher than the amount needed to prevent deficiency. Current recommendations on vitamin B12 intake of 1.4-3.0 $\mu \mathrm{g}$ may be inadequate to maintain body stores of $1.1-3.9 \mathrm{mg}$ and optimal plasma concentrations of markers of vitamin B12 status. However, evidence on daily vitamin B12 losses and bioavailability could only be derived from relatively old studies published between 1958 and 1991 and can hardly be updated because this requires invasive methods or the use of isotopes that do not comply with current ethical standards. In view of this, establishing recommended vitamin B12 intakes with the factorial approach can be based on evidence on the rate of loss (a relatively accurate and precise estimate) and bioavailability (large variability and uncertainty), together with an estimate of the re- quired total body stores (crude estimate). However, the available evidence is rather scarce and resulting estimates have considerable uncertainty. The commonly used CV of $10-20 \%$ seems too low to cover uncertainty in all these underlying assumptions and may be at least $24 \%$. More evidence is needed on the relationship between plasma concentrations of markers for the vitamin B12 status, vitamin B12 body stores and long-term health outcomes to evaluate whether the currently recommended intake of vitamin B12 intake need to be changed.

\section{Acknowledgments}

We thank Rachel Collings (University of East Anglia) and Maresa Duffy (University of Ulster) for their assistance during the identification and selection of papers for this review. The work reported herein has been carried out within the EURRECA Network of Excellence (www.eurreca.org), which is financially supported by the Commission of the European Communities, a specific research, technology and development program Quality of Life and Management of Living Resources, within the Sixth Framework Program, project No. 036196. This report does not necessarily reflect the Commission's views or its future policy in this area.

\section{References}

1 Doets EL, Cavelaars AE, Dhonukshe-Rutten RA, van 't Veer P, de Groot LC: Explaining the variability in recommended intakes of folate, vitamin B12, iron and zinc for adults and elderly people. Public Health Nutr 2012;15: 906-915.

2 Martin A: The 'Apports nutritionnels conseillés' (ANC) for the French population, ed 3. CNRS/CNERNA/AFSSA. Paris, Tec \& Doc Lavoisier, 2001.

3 Aggett PJ: Population reference intakes and micronutrient bioavailability: a European perspective. Am J Clin Nutr 2010;91:1433S1437S.

4 Allen LH: Bioavailability of vitamin B12. Int J Vitam Nutr Res 2010;80:330-335.

5 Food and Nutrition Board/Institute of Medicine (FNB/IOM): Dietary Reference Intakes for Thiamin, Riboflavin, Niacin, Vitamin B6, Folate, Vitamin B12, Pantothenic Acid, Biotin, and Choline. Washington, National Academy Press, 1998.

6 Health Council of the Netherlands: Dietary Reference Intakes: Vitamin B6, Folic Acid, and Vitamin B12. Publ No 2003/04. The Hague, Health Council of the Netherlands, 2003.

7 Watanabe F: Vitamin B12 sources and bioavailability. Exp Biol Med (Maywood) 2007; 232:1266-1274. $\checkmark 8$ Doscherholmen A, McMahon J, Economon P: Vitamin B12 absorption from fish. Proc Soc Exp Biol Med 1981;167:480-484.

$\checkmark 9$ Doscherholmen A, McMahon J, Ripley D: Vitamin B12 absorption from eggs. Proc Soc Exp Biol Med 1975;149:987-990.

10 Doscherholmen A, McMahon J, Ripley D: Vitamin B12 assimilation from chicken meat. Am J Clin Nutr 1978;31:825-830.

11 Heyssel RM, Bozian RC, Darby WJ, Bell MC: Vitamin B12 turnover in man. The assimilation of vitamin B12 from natural foodstuff by man and estimates of minimal daily dietary requirements. Am J Clin Nutr 1966;18:176184.

12 Russell RM, Baik H, Kehayias JJ: Older men and women efficiently absorb vitamin B-12 from milk and fortified bread. J Nutr 2001; 131:291-293.

13 Carmel R: Discussion: causes of vitamin B-12 and folate deficiencies. Food Nutr Bull 2008; 29:S35-S37.

14 Smith DA, Refsum H: Do we need to reconsider the desirable blood level of vitamin B12? J Intern Med 2012;271:179-182.

15 Dullemeijer C, Souverein OW, Doets EL, van der Voet $\mathrm{H}$, van Wijngaarden JP, de Boer WJ, Plada M, Dhonukshe-Rutten RAM, In 't Veld $\mathrm{PH}$, Cavelaars AEJM, de Groot LCPGM, van 't
Veer P: Systematic review with dose-response meta-analyses between vitamin B-12 intake and European Micronutrient Recommendations Aligned's prioritized biomarkers of vitamin B-12 including randomized controlled trials and observational studies in adults and elderly. Am J Clin Nutr 2013;97:390-402.

16 Bozian RC, Ferguson JL, Heyssel RM, Meneely GR, Darby WJ: Evidence concerning the human requirement for vitamin B12. Use of the whole body counter for determination of absorption of vitamin B12. Am J Clin Nutr 1963;12:117-129.

17 Food and Agricultural Organization/World Health Organization (FAO/WHO): Requirements of Ascorbic Acid, Vitamin D, Vitamin B12, Folate, and Iron. WHO Technical Report Series No 452. Geneva, WHO, 1970.

18 el Kholty S, Gueant JL, Bressler L, Djalali M, Boissel P, Gerard P, Nicolas JP: Portal and biliary phases of enterohepatic circulation of corrinoids in humans. Gastroenterology 1991;101:1399-1408.

19 Gueant JL, Djalali M, Aouadj R, Gaucher P, Monin B, Nicolas JP: In vitro and in vivo evidences that the malabsorption of cobalamin is related to its binding on haptocorrin ( $\mathrm{R}$ binder) in chronic pancreatitis. Am J Clin Nutr 1986;44:265-277. 
20 Adams JF, Ross SK, Mervyn L, Boddy K, King P: Absorption of cyanocobalamin, coenzyme B 12, methylcobalamin, and hydroxocobalamin at different dose levels. Scand J Gastroenterol 1971;6:249-252.

-21 Matthys C, van 't Veer P, de Groot L, Hooper L, Cavelaars AE, Collings R, Donutske-Rutten R, Harvey LJ, Casgrain A, Rollin F, Contor L: EURRECA's Approach for Estimating Micronutrient Requirements. Int J Vitam Nutr Res 2011;81:256-263.

-22 Adams JF, Boddy K: Metabolic equilibrium of tracer and natural vitamin B12. J Lab Clin Med 1968;72:392-396.

23 Boddy K, Adams JF: Excretion of cobalamins and coenzyme B 12 following massive parenteral doses. Am J Clin Nutr 1968;21:657-664.

24 Reizenstein P, Ek G, Matthews CM: Vitamin B-12 kinetics in man. Implications on totalbody-B-12-determinations, human requirements, and normal and pathological cellular B12 uptake. Phys Med Biol 1966;11:295-306.

25 Grasbeck R, Nyberg W, Reizenstein P: Biliary and fecal vit. B12 excretion in man: an isotope study. Proc Soc Exp Biol Med 1958;97:780-784.

26 Reizenstein PG: Excretion, enterohepatic circulation, and retention of radiovitamin B12 in pernicious anemia and in controls. Proc Soc Exp Biol Med 1959;101:703-707.

$\checkmark 27$ Doscherholmen A, McMahon J, Ripley D: Inhibitory effect of eggs on vitamin B12 absorption: description of a simple ovalbumin $57 \mathrm{Co}-$ vitamin B12 absorption test. Br J Haematol 1976;33:261-272.

-28 Doscherholmen A, Swaim WR: Impaired assimilation of egg Co 57 vitamin B 12 in patients with hypochlorhydria and achlorhydria and after gastric resection. Gastroenterology 1973;64:913-919.

29 Kittang E, Hamborg B, Schjonsby H: Absorption of food cobalamins assessed by the double-isotope method in healthy volunteers and in patients with chronic diarrhoea. Scand J Gastroenterol 1985;20:500-507.

- 30 Ardeman S, Chanarin I, Berry V: Studies on human gastric intrinsic factor: observations on its possible absorption and entero-hepatic circulation. Br J Haematol 1965;11:11-14.

-31 Reizenstein PG, Nyberg W: Intestinal absorption of liver-bound radiovitamin B12 in patients with pernicious anaemia and in controls. Lancet 1959;ii:248-252.

-32 Adams JF, Tankel HI, Macewan F: Estimation of total body vitamin-B12 in live subjects. Clin Sci 1970;39:107-113.

- 33 Bessent RG, Watson WS, Macdonald C, Adams JF: Application of the occupancy principle in studies of the metabolism of vitaminB12 in man. Clin Sci 1980;58:169-171.

- 34 DerSimonian R, Laird N: Meta-analysis in clinical trials. Control Clin Trials 1986;7:177188.

-35 Higgins JPT, Thompson SG: Quantifying heterogeneity in a meta-analysis. Stat Med 2002; 21:1539-1558.
36 Deller DJ, Germar H, Witts LJ: Effect of food on absorption of radioactive vitamin B12. Lancet 1961;i:574-577.

37 Halsted JA, Lewis PM, Hvolboll EE, Gasster M, Swendseid ME: An evaluation of the fecal recovery method for determining intestinal absorption of cobalt60-labeled vitamin B12. J Lab Clin Med 1956;48:92-101.

38 Heinle RW, Welch AD, Scharf V, Meacham GC, Prusoff WH: Studies of excretion (and absorption) of Co60 labeled vitamin B12 in pernicious anemia. Trans Assoc Am Physicians 1952;65:214-222.

39 Chanarin I: The Megaloblastic Anaemias. Oxford, Blackwell Scientific, 1969.

40 Myhre E: Studies on megaloblasts in vitro. II. Maturation of nucleated red cells in pernicious anemia before and during treatment with vitamin B 12 . Scand J Clin Lab Invest 1964;16:320-331.

41 Samson D, Halliday D, Chanarin I: Reversal of ineffective erythropoiesis in pernicious anaemia following vitamin B12 therapy. Br J Haematol 1977;35:217-224.

42 Carmel R: Pernicious anemia. The expected findings of very low serum cobalamin levels, anemia, and macrocytosis are often lacking. Arch Intern Med 1988;148:1712-1714.

43 Savage DG, Lindenbaum J, Stabler SP, Allen RH: Sensitivity of serum methylmalonic acid and total homocysteine determinations for diagnosing cobalamin and folate deficiencies. Am J Med 1994;96:239-246.

44 Carmel R, Sinow RM, Siegel ME, Samloff IM: Food cobalamin malabsorption occurs frequently in patients with unexplained low serum cobalamin levels. Arch Intern Med 1988; 148:1715-1719.

-45 Lindenbaum J, Savage DG, Stabler SP, Allen RH: Diagnosis of cobalamin deficiency. II. Relative sensitivities of serum cobalamin, methylmalonic acid, and total homocysteine concentrations. Am J Hematol 1990;34:99107.

46 Stabler SP, Allen RH, Savage DG, Lindenbaum J: Clinical spectrum and diagnosis of cobalamin deficiency. Blood 1990;76:871881.

47 Healton EB, Savage DG, Brust JC, Garrett TJ, Lindenbaum J: Neurologic aspects of cobalamin deficiency. Medicine (Baltimore) 1991; 70:229-245.

48 Savage DG, Lindenbaum J: Neurological complications of acquired cobalamin deficiency: clinical aspects. Baillieres Clin Haematol 1995;8:657-678.

49 Joske RA: Vitamin B12 content of human liver tissue obtained by aspiration biopsy. Gut 1963;4:231-235.

50 Kato N, Narita Y, Kamohara S: Liver vitamin B 12 levels in chronic liver diseases. J Vitaminol (Kyoto) 1959;5:134-40.
1 Pitney WR, Onesti P: Vitamin B12 and folic acid concentrations of human liver with reference to the assay of needle biopsy material. Aust J Exp Biol Med Sci 1961;39:1-7.

52 Stahlberg KG, Radner S, Norden A: Liver B12 in subjects with and without vitamin B12 deficiency. A quantitative and qualitative study. Scand J Haematol 1967;4:312-330.

53 Swendseid ME, Hvolboll E, Schick G, Halsted JA: The vitamin-B12 content of human liver tissue and nutritional significance - a comparison study of various age groups. Blood 1957;12:24-28.

54 de la Grandmaison GL, Clairand I, Durigon M: Organ weight in 684 adult autopsies: new tables for a Caucasoid population. Forensic Sci Int 2001;119:149-154.

55 Vinas BR, Barba LR, Ngo J, Gurinovic M, Novakovic R, Cavelaars A, de Groot LCPGM, van't Veer P, Matthys C, Majem LS: Projected prevalence of inadequate nutrient intakes in Europe. Ann Nutr Metab 2011;59:84-95.

56 Tucker KL, Rich S, Rosenberg I, Jacques P, Dallal G, Wilson PW, Selhub J: Plasma vitamin B-12 concentrations relate to intake source in the Framingham Offspring study. Am J Clin Nutr 2000;71:514-522.

57 Vogiatzoglou A, Smith AD, Nurk E, Berstad P, Drevon CA, Ueland PM, Vollset SE, Tell GS, Refsum H: Dietary sources of vitamin B-12 and their association with plasma vitamin B-12 concentrations in the general population: the Hordaland Homocysteine Study. Am J Clin Nutr 2009;89:1078-1087.

58 Bor MV, Lydeking-Olsen E, Moller J, Nexo E: A daily intake of approximately 6 microg vitamin B-12 appears to saturate all the vitamin B-12-related variables in Danish postmenopausal women. Am J Clin Nutr 2006;83:5258.

59 Bor MV, von Castel-Roberts KM, Kauwell GP, Stabler SP, Allen RH, Maneval DR, Bailey LB, Nexo E: Daily intake of 4 to 7 microg dietary vitamin B-12 is associated with steady concentrations of vitamin B-12-related biomarkers in a healthy young population. Am J Clin Nutr 2010;91:571-577.

60 Kwan LL, Bermudez OI, Tucker KL: Low vitamin B-12 intake and status are more prevalent in Hispanic older adults of Caribbean origin than in neighborhood-matched nonHispanic whites. J Nutr 2002;132:2059-2064.

61 Carmel R: Biomarkers of cobalamin (vitamin B-12) status in the epidemiologic setting: a critical overview of context, applications, and performance characteristics of cobalamin, methylmalonic acid, and holotranscobalamin II. Am J Clin Nutr 2011;94:348S-358S.

62 Andres E, Vidal-Alaball J, Federici L, Loukili $\mathrm{NH}$, Zimmer J, Kaltenbach G: Clinical aspects of cobalamin deficiency in elderly patients. Epidemiology, causes, clinical manifestations, and treatment with special focus on oral cobalamin therapy. Eur J Intern Med 2007;18: 456-462. 